\title{
Jednostka leksykalna барем i jej polskie odpowiedniki — próba analizy semantycznej i składniowej (na podstawie przekładów prozy macedońskiej na język polski i polskiej na język macedoński)
}

Przedmiotem niniejszego artykułu jest jednostka leksykalna барем występująca we współczesnym języku macedońskim, mająca na celu ukazanie funkcji semantycznych i syntaktycznych pełnionych w tekście przez konkretny leksem. Przyjęta przeze mnie metodologia badawcza opiera się na konfrontacji znaczenia i zakresu użycia analizowanej partykuły w stosunku do języka polskiego, dlatego też korpus stanowiący podstawę badań zaczerpnięty został z utworów współczesnej literatury pięknej języka macedońskiego i ich przekładów na język polski oraz odwrotnie ${ }^{1}$. Dzięki przedstawieniu polskich ekwiwalentów badanej jednostki leksykalnej, na podstawie analizy semantycznej oraz syntaktycznej, będę mogła pokazać podobieństwa i różnice zakresu użycia i znaczenia występujące w obu językach.

Rozległa i niezwykle złożona problematyka partykuł znajduje swoje stosunkowo bogate odzwierciedlenie w słowiańskich badaniach lingwistycznych, jednak w niektórych językach ich stan ciągle daleki jest od zadowalającego. Prezentowane uwagi mają charakter wstępny i stanowią propozycję do głębszych rozważań na temat macedońskich partykuł $\mathrm{i}$ ich roli we współczesnej komunikacji.

${ }^{1}$ Wybrane przeze mnie pozycje to: Л. Старова, Времето на козите - Czasy kóz, przetłumaczone na język polski przez Dorotę Jovankę Cirlić, oraz W. Kuczok, Gnój-Íyбpe, przethumaczone na język macedoński przez Natalię Łukomską i Filipa Dimevskiego. Niektóre przykłady pochodzą także z korpusu zaczerpniętego z Дигитален речник на македонскиот јазик oraz powieści Жарко Кујунџиски Америка. 
Podczas gdy lingwistyka polska doczekała się wielu prac monograficznych poświęconych problematyce partykuł, zarówno w ujęciu synchronicznym ${ }^{2}$, jak i diachronicznym $^{3}$, w językoznawstwie macedońskim powstała tylko jedna monografia opisująca tę klasę leksemów, której autorką jest Lidija Arizankovska. Nie stanowi ona jednak kompleksowego opracowania tematu, gdyż autorka skupia się wyłącznie na analizie czterech partykuł macedońskich w konfrontacji z językiem słoweńskim.

Na początku rozważań przedstawię definicję wyrażeń funkcyjnych w języku polskim i macedońskim, do których zaliczane są partykuły. Czynię tak, ponieważ częstym zjawiskiem językowym jest homonimia leksemów - mianowicie obok funkcji modalnych pełnią one również funkcje spójnika.

Wyrazy funkcyjne to według Macieja Grochowskiego

ogólna nazwa zbioru klas jednostek słownikowych, określanych jako syntaktycznie niesamodzielne (inaczej niepełnoznaczne, synsemantyczne). Przyjmuje się, że jednostkami funkcyjnymi są przyimki, zaimki, spójniki, partykuły, a także liczne inne wyrażenia, które z jednej strony odgrywają istotną rolę w procesie tworzenia zdania i tekstu, w procesie ich oceny przez mówiącego, a z drugiej nie mają bezpośredniego odniesienia do świata pozajęzykowego ${ }^{4}$.

Zawarta w Stowniku gniazdowym partykut polskich definicja partykuły określa ją natomiast jako:

operator metatekstowy (jednostkę leksykalną mającą referencję do mówiącego i do użytych w wypowiedzeniu wyrażeń): (1) otwierającą jedną pozycję dla rematu wypowiedzenia, nienacechowaną gramatycznie (to znaczy zarówno dla wyrazów reprezentujących różne części mowy, jak i dla grup syntaktycznych i zdań) ani semantycznie (czyli niewymagający danego komponentu treści), (2) współwystępującą z wyrażeniami wypełniającymi tę pozycję, ale niewchodzącymi z nimi w zależność syntaktyczną, (3) niewchodzącą samodzielnie na pozycje otwierane przez jednostki innych klas gramatycznych, (4) komentujące remat wypowiedzenia ${ }^{5}$.

Podobnie partykuły definiują macedońscy lingwiści, którzy także zwracają uwagę, że trudno oddzielić je od innych wyrazów nieodmiennych, takich jak przysłówki, spójniki czy wyrazy modalne:

Частиците или партикулите служат за истакнување на други зборови или на значењето на целата реченица, како и за определувања од различен вид посочување, негирање, прашање. Во поголемиот дел тоа се зборови што се јавуваат и како прилози и сврзници, но нивната функција е, кога идат како партикули, подруга ${ }^{6}$.

${ }^{2}$ Można tu przywołać monografię Macieja Grochowskiego oraz cząstkowe ujęcia zawarte w pracach Magdaleny Danielewiczowej.

${ }^{3}$ Opis partykuł w ujęciu diachronicznym obecny jest między innymi w najnowszych publikacjach grantowych pod red. Krystyny Kleszczowej.

${ }^{4}$ M. Grochowski, Pojęcie jednostki funkcyjnej. Z historii metodologii składni polskiej, [w:] Wyrażenia funkcyjne w perspektywie diachronicznej, synchronicznej i porównawczej, red. K. Kleszczowa, A. Szczepanek, Katowice 2014, s. 13.

${ }^{5}$ M. Grochowski, A. Kisiel, M. Żabowska, Stownik gniazdowy partykut polskich (dalej: SGGP), Kraków 2014, s. 26.

${ }^{6}$ К. Конески, Граматика на македонскиот јазик, Скопје 2004, s. 541. 
Szerzej zagadnienie to zostało przedstawione w definicji Liljany Minowej-G’urkovej, która uzupełnia definicję o informację:

одделни партикули учествуваат во градењето на некои форми (глаголски, заменски и сл.), поголем број партикули играат важна улога во модалната карактеристика на исказот. Други пак учествуваат во поврзувањето на одделни реченици, или групи од реченици, со што се јавуваат како средства за поврзување во рамките на текстот ${ }^{7}$.

Najnowsza definicja wspomnianej macedońskiej badaczki L. Arizankovskiej opiera się w dużym stopniu na polskiej definicji M. Grochowskiego i określa partykuły jako:

неменливи зборови кои немаат постојана синтаксичка позиција, односно го менуваат местото во реченицата (за разлика од пролозите, предлозите и сврзниците). Тие се од семантичка гледна точка предикати, имаат широка зона на подвижност и ја менуваат тематско-рематската структура на реченицата. Можат да го потенцираат секој составен дел на реченицата кој има лексичко значење ${ }^{8}$.

Wszystkie przedstawione definicje, pomimo że koncentrują się na odmiennych funkcjach partykuł, są analogiczne i podkreślają fakt, iż służą one głównie wyrażaniu różnych odmian modalności w zdaniach. Zwracają także uwagę na częstą polifunkcjonalność tego rodzaju wyrazów, to jest możliwość użycia partykuł w zdaniu również w funkcji spójników, przysłówków czy wykrzykników, z tą jednak różnicą, że w odróżnieniu od przysłówków — partykuły nie mają własnego znaczenia leksykalnego, a w przeciwieństwie do wykrzykników — nie posiadają nacechowania emocjonalnego. Różnicę pomiędzy partykułą a spójnikiem stanowi fakt, iż partykuły nie mają możliwości spajania wypowiedzi. Podobny jest też podział partykuł we współczesnym języku macedońskim, wyróżniający na przykład partykuły potwierdzające, pytające czy negujące. Te zarysowane własności leksemów funkcyjnych (partykuł) występują również w innych językach słowiańskich. Nie zawsze można też jednoznacznie orzec, którą funkcję uznać za wyjściową/ podstawową.

Dla uzyskania pełnego obrazu zakresu funkcji leksemu барем przejdę do analizy jego semantycznych i syntaktycznych funkcji.

Etymologia wyrazu wskazuje na pochodzenie perskie/tureckie od leksemu bari: „ба̀ре, барѐм, барѝм, бар нареч., разг. 'поне', нѐбаре 'уж’ (Кичевско), прѝбаре 'почти' (Щип), вж. бо̀жем" dniowosłowiańskich - bułgarskim oraz w językach opartych na dialekcie sztokawskim.

Definicja zawarta w Słowniku języka macedońskiego określa go jako: „Барем — чест., Изразува извесно ограничување”. Na język polski thumaczona jest

7 Л. Минова-Ѓуркова, Синтакса на македонскиот стандарден јазик, Скопје 2000, s. 83.

8 Л. Аризанковска, Како да се претстават партикулите во планираниот толковен речник на македонскиот јазик, [w:] Норма и речник, Скопје 2002, s. 609.

${ }^{9}$ Български етимологичен речник, t. 1. A-3, Съставили: Вл. Георгиев, Ив. Гълъбов, Й. Заимов, Ст. Илчев, Ред. Вл. И. Георгиев, София 1971, s. 33. 
jako: choć, chociaż, przynajmniej, na przykład: „Сакам барем уште еднаш да те видам [Chcę jeszcze chociaż raz Cię zobaczyć]”10; „И јас би сакала да бидам јака, Кети, за да можам да работам исто како тебе. Барем ќе се обидам [I ja chciałabym być mocna, Keti, żebym mogła pracować tak jak ty. Chociaż/przynajmniej spróbuję]”11; „Морнари од сите страни на светот го барале, но не можеле да стасаат, барем не со чамците кои ги граделе [Szukali go marynarze z całego świata, lecz nie mogli go uratować, przynajmniej nie na łodziach, które budowali]”12; „Момчето беше дисциплинирано, никогаш не му беше нагласено, но чувстуваше дека не треба да го издаде суштеството, пред никого, барем не засега [Chłopiec był zdyscyplinowany, nigdy nie było mu powiedziane, ale czuł, że nie powinien pokazywać potwora przed nikim, przynajmniej nie teraz]”13; „Беше тоа Џорџ Батфорд, барем така се претстави, пропаднат и блед [To był George Batford, przynajmniej tak się przedstawił, wykończony i blady]"14.

Omawiana partykuła należy do grupy partykuł limitatywnych, wzmacniających - mających na celu pokazanie świadomego ograniczenia ze strony nadawcy. Oznacza pewną dolną akceptowalną granicę tego, o czym jest mowa. Mimo iż, tak jak wspomniałam, w języku polskim możemy ją tłumaczyć, używając synonimów: choć, chociaż, przynajmniej, to słownik języka macedońskiego nie odnotowuje wyrazów bliskoznacznych dla leksemu барем.

Interesujące jest, jak analizowany leksem tłumaczony jest w przekładach literatury pięknej na język polski. Przykłady zostały wyekscerpowane z powieści Времето на козите Luana Starovy: „Каде се чуло видело коза да носи име на великиот ослободител на народите. Барем да беше јарец... Не, не ни, јарец, што зборувам [Kto to słyszał, żeby koza nosiła imię wielkiego wyzwoliciela narodów?! Niechby to chociaż był kozioł. Nie, nie, kozioł też nie, co ja wygaduje]”"15; „Тие сакаа да останат верни кон нешто неопределено, што не беше ниту идеал. А барем да беше тоа, тогаш ќе имаше изгледи за некаква промена во мислењето, надеж [Chcieli być wierni czemuś nieokreślonemu, со z pewnością nie było ideałem. Bo gdyby to był ideał, moglibyśmy przynajmniej liczyć na zmianę ich myślenia, moglibyśmy mieć nadzieję]”16; „Мајка ми му предложи барем сега да направи исклучок, да ја остави дома [Matka zaproponowała, by choć raz zrobił wyjątek i zostawił go w domu]"17.

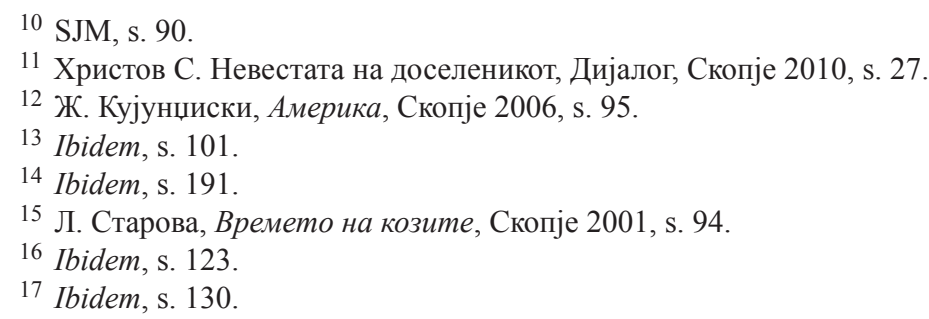


W powyższych przykładach widać, że w języku polskim leksemowi барем mogą odpowiadać trzy bliskie sobie partykuły: choć, chociaż i przynajmniej ${ }^{18}$. Zgodnie z eksplikacją zawartą w SGPP należą one do grupy partykuł porównywania - limitatywnych. Mimo iż w większości słowników języka polskiego uważane są za synonimy, nie w każdym kontekście można je za takowe uznać. Zamieszczona poniżej egzemplifikacja pokaże, że w języku macedońskim mogą być one tłumaczone tylko jako барем. Posłużę się teraz przykładami z polskiej powieści Gnój Wojciecha Kuczoka i jej tłumaczeniem na język macedoński.

„Dobrze chociaż, że to jacyś porządni ludzie, mogliśmy gorzej trafić, przecież się nie awanturują" [„Добро е барем што се некоипримерни луѓе, можеше полошо да ни се погоди, сепак не се расправаат”] ${ }^{19}$; „,sukienkę matka zaszywała, a siniaki stanowiły przynajmniej kilkudniową barierę ochronną, bo już nawet i seniorom rodów grabarskich serca wzburzały" [„,здолништето мајката го сошиваше, а модринките претставуваа барем неколкудневна заштитна бариера, бидејќи дури и срцата на постарите од гробарските родови веќе почнаа да се возбудуваат”] ${ }^{20}$; „,nie zwraca uwagi nawet wtedy, kiedy się za nami oglądają i wrzeszczą, że można by chociaż przeprosić” [,„ури ниту тогаш не ги забележуваш кога по нас се загледуваат и врескаат дека барем би можело да се извиниш"] $]^{21}$; ,ja wiem, to jest dobre, ale nie mógłbyś raz czegoś ładnego namalować, choćby mój portret albo córeczki naszej...” [,,jас знам, тоа е добро, но не можеш ли еднаш нешто убаво да насликаш, барем мој портрет или од нашата ќерка...”] ${ }^{22}$; „I wysłali, do wielkiego dziecięcego sanatorium, podania o przyjęcie mnie, na kilka oddziałów wysłali z nadzieją, że choć jeden wniosek przyniesie skutek” [„И испратија, до големиот детски санаториум, писмо да ме примат, испратија до неколку одделенија со надеж дека барем една молба ќе даде резултат”] ${ }^{23}$; „Sam odpalił, sam rzucił i sam czekał na wybuch, potem chociaż na małe puknięcie, choćby z wdzięczności za podróż z poligonu" [„Самиот ја запали, самиот ја фрли и самиот ја чекаше експлозијата, потоа барем мало пукнување, барем од благодарност за патот од полигонот"] ${ }^{24}$.

Przykłady te ilustrują bogatszy inwentarz leksykalny języka polskiego i zarazem większy semantyczny zakres użycia partykuły барем w języku macedońskim. W większości przypadków w języku polskim każdy z nich można zamienić pozostałymi synonimami, należy jednak pamiętać, że na przykład partykuła przy-

${ }^{18} \mathrm{~W}$ artykule skupiam się tylko na ich odniesieniu do бapen, nie poddając ich autonomicznej analizie.

\footnotetext{
${ }^{19}$ В. Кучок, Ѓ убре, Скопје 2010, s. 6.

20 Ibidem, s. 7.

${ }^{21}$ Ibidem, s. 13.

22 Ibidem, s. 41.

${ }^{23}$ Ibidem, s. 77.

24 Ibidem, s. 71.
} 
najmniej nie zawiera komponentu wolitywnego, w przeciwieństwie do chociaż 25 . Dla wszystkich natomiast typowym, wspólnym kontekstem są struktury niedeklaratywne i stwierdzenia komunikujące wolę. Istotne jest także, iż w języku polskim wyrażenia funkcyjne choć, chociaż posiadają jednostki homonimiczne w postaci spójników wprowadzających zdanie podrzędne przyzwalające, natomiast macedoński leksem барем klasyfikowany jest wyłącznie jako partykuła, a funkcję spójnika odpowiadającego chociaż pełni leksem иако.

Jeżeli chodzi o cechy syntaktyczne барем, a dokładniej jej miejsce w szyku zdania, należy stwierdzić, że szyk partykuł i miejsce akcentu zdaniowego ma istotny wpływ na strukturę tematyczno-rematyczną zdań. W języku macedońskim partykuła może być użyta w odniesieniu do składnika występującego bezpośrednio przed nią oraz $\mathrm{w}$ stosunku do innego elementu, niesąsiadującego z nią linearnie.

Na podstawie dostępnego korpusu można w dużej mierze określić mobilność składniową jednostki leksykalnej барем. Zgodnie z modelem mobilności syntaktycznej zawartym w monografii Arizankovskiej partykuły mogą występować w zdaniu w następujących pozycjach:

1. Przed predykatem: „Теоретски секоја земја може да изгради нуклеарна електрична централа, или барем може гласно да размислува за ваква идеја".

2. Przed przysłówkiem wchodzącym w skład wyrażenia predykatywnego: „Тие ќе се борат за срцето на принцот Хари! Или барем така се надеваат”.

3. Przed grupą nominalną w funkcji wyrażenia argumentowego: „Странците очекуваат барем насмевка од охриѓани".

4. Przed nazwą własną: „Сакам барем Јана пак да видам”.

5. Przed okolicznikiem (np. ilości) wbudowanym w grupę imienną w funkcji wyrażenia argumentowego: „Работи кои мора да ги направите барем еднаш во животот".

6. Przed okolicznikiem czasu: „Железните порти кај летната сцена Св. Софија барем денски да бидат отворени бараат жителите на »Илиднеска«".

7. Przed okolicznikiem miejsca: „Поставете го преку целата просторија или барем онаму каде што се наоѓа најголемиот дел од мебелот”.

Patrząc na szyk zdania w języku macedońskim, daje się zauważyć, że бapeм może zajmować różne pozycje w zdaniach. Ponadto w języku mówionym może ją zmieniać w obrębie jednego zdania, w zależności od miejsca akcentu wyrazowego; natomiast $\mathrm{w}$ języku pisanym w szyku neutralnym najczęściej pojawia się w środku zdania, co nie wyklucza jej obecności na początku jako nośnika akcentu wyrazowego, na przykład: „Пробај барем еднаш może brzmieć: Барем еднаш пробај”.

Z powyższych rozważań wynika, że барем w języku macedońskim jest jednosegmentową jednostką leksykalną, nieposiadającą homonimów, która pełni w zdaniu funkcję tylko partykuły. Widać tutaj zatem różnicę w stosunku do języka polskiego, w którym leksem chociaż pełni najczęściej funkcję spójnika

${ }^{25}$ M. Grochowski, A. Kisiel, M. Żabowska, op. cit., s. 254. 
wprowadzającego podrzędne zdanie przyzwalające, a jako synonim wyrazu przynajmniej występuje w zdaniu w roli partykuły. Барем wyraża minimalny, możliwy do zaakceptowania zakres czegoś lub komunikuje, że ilość czegoś jest nie mniejsza od wymienionej, choć może być większa. Charakteryzuje się zmiennym szykiem w zdaniu. Z moich obserwacji wynika, że nie odznacza się dużą frekwencją, ponieważ na przykład w powieści Czasy kóz występuje zaledwie cztery razy. Z powodu braku słownika frekwencyjnego w języku macedońskim można jednak wysnuć tylko przypuszczenie, że jej użycie, jak też innych elementów w ogóle, zależy od konkretnego gatunku wypowiedzi, jego celów i treści.

\section{Bibliografia}

Danielewiczowa M., ,C Czy aby Maciej mi przytaknie?” O statusie ,, aby” w pytaniach rozstrzygnięcia, „Linguistica Copernicana” 2012, nr 1 (7).

Encyklopedia języka polskiego, red. S. Urbańczyk, M. Kucała, Zakład Narodowy im. Ossolińskich, Wrocław 1999.

Encyklopedia językoznawstwa ogólnego, red. K. Polański, Zakład Narodowy im. Ossolińskich, Wroclaw 1999.

Grochowski M., Koncepcja stownika partykut polskich, „Slavica Wratislaviensia” 150, 2009.

Grochowski M., Kryteria opozycji homonimicznych partykut i przysłówków, „Slavica Wratislaviensia” 159, 2014.

Grochowski M., O strukturze semantycznej zdań z partykuła „,chociaz”, „Polonica” 8, 1982.

Grochowski M., Pojęcie jednostki funkcyjnej. Z historii metodologii sktadni polskiej, [w:] Wyrażenia funkcyjne w perspektywie diachronicznej, synchronicznej i porównawczej, red. K. Kleszczowa, A. Szczepanek, Wydawnictwo Uniwersytetu Śląskiego, Katowice 2014.

Grochowski M., Polskie partykuty. Sktadnia, semantyka, leksykografia, Wydawnictwo Polskiej Akademii Nauk, Wrocław 1986.

Grochowski M., Wyrażenia funkcyjne. Studium leksykograficzne, Wydawnictwo Instytut Języka Polskiego Polskiej Akademii Nauk, Kraków 1997.

Grochowski M., Kisiel A., Żabowska M., Stownik gniazdowy partykut polskich, Polska Akademia Umiejętności, Kraków 2014.

Klemensiewicz Z., O rzadszych funkcjach syntaktycznych wyrazu choć i podobnych, „Język Polski” 4, 1957.

Kleszczowa K., Termińska K., Genetyczne parentele partykut i spójników, „LingVaria” 10, 2015.

Kuczok W., Gnój, Wydawnictwo W.A.B., Warszawa 2003.

Starova L., Czasy kóz, przeł. D. Jovanka Ćirlić, Oficyna 21, Warszawa 2005.

Stępień M., Zniewolone partykuły. Wyrażenia funkcyjne jako narzędzia w semantyce składnikowej, „Linguistica Copernicana” 2010, nr 2 (4).

Żabowska M., Partykutologia i partykułografia. Stan obecny i perspektywy, [w:] Maiuscula linguistica: studia in honorem professori Matthiae Grochowski sextuagesimo quinto dedicata, red. A. Moroz, P. Sobotka, M. Żabowska, Bel Studio, Warszawa 2014.

Żabowska M., Zróżnicowanie semantyczne partykuł epistemicznych, „LingVaria” 1, 2006.

Аризанковска Л., Како да се претстават партикулите во планираниот толковен речник на македонскиот јазик, [w:] Норма и речник, Универзитет Св. Кирил и Методиј, Скопје 2002. 
Аризнаковска Л., За партикулите во македонскиот, словенечкиот и полскиот јазик, [w:] Folia Philologica Macedono-Polonica, Универзитет Св. Кирил и Методиј, Скопје 2011.

Аризнаковска Л., Од семантиката и синтаксата на дел од словенечките и македонските партикули, Универзитет Св. Кирил и Методиј, Скопје 2007.

Български етимологичен речник, t. 1. A-3, Съставили: Вл. Георгиев, Ив. Гъльбов, Й. Заимов, Ст. Илчев, Ред.: Вл. И. Георгиев, София: Изд. на БАН, София 1971.

Дигитален речник на македонскиот јазик, http://www.makedonski.info.

Старова Л., Времето на козите, Матица Македонска, Скопје 2001.

Конески К., Граматика на македонскиот јазик, Детска Радост, Скопје 2004.

Кујунџиски Ж., Америка, Антолог, Скопје 2006.

Кучок В., Губбре, прев. Лукомска Наталија, Димевски Филип, Македонска Реч, Скопје 2010.

Минова-Гууркова Л., Синтакса на македонскиот стандарден јазик, Универзитет Св. Кирил и Методиј, Скопје 2000.

Македонско-полски и полско-македонски речник, red. B. Vidoeski, W. Pianka, Z. Topolińska, Wydawnictwo PWN, Warszawa-Skopje 1990.

Речник на македонски јазик (со српскохрватски толкувања), red. Б. Конески, Детска Радост, Скопје 1994.

Толковен речник на македонскиот јазик, red. К. Конески, Универзитет Св., Кирил и Методиј, Скопје 2011.

\section{Lexical unit барем — semantic and syntactic analysis}

Summary

This study aims to show what semantic and syntactic features has a lexical unit барем in the contemporary Macedonian language. On the basis of confrontation of meaning and scope of the use of the tested particles in Polish and Macedonian, the author points to the similarities and differences in both languages. The results of the analysis show that Polish has richer lexical inventory. They show the versatility of particle барем in Macedonian and also prove that барем is one-segment lexical unit, which is used as a particle in the sentences and has no homonyms in Macedonian.

Keywords: particle, semantics, homonymy, conjunction, function expression

\section{Барем - семантичка и ситаксичка анализа}

Резиме

Оваа статија има за цел да го покаже какви карактеристични функции - семантички и синтаксички има зборот барем во современиот македонски јазик. Врз основа на конфронтација на значењето и опсегот на употребата на испитуваната честичка во полски и македонски јазик, авторката ги укажува сличностите и разликите во двата јазика. Резултатите од анализата покажуваат побогат инвентар во полската лексика и, исто така, флексибилност на честичката барем во македонскиот јазик и докажуваат дека барем е еден сегмент лексички единици, кои служат во реченицата само како честичка, нема хомоними во македонски јазик.

Клучни зборови: Честички, семантика, хомонимија, сврзник 